\title{
Jevišovická kultura na východní Moravě?
}

\section{Jevišovice Culture in East Moravia?}

\author{
Jaroslav Peška
}

\begin{abstract}
Abstrakt
Mezi materiálem ze záchranného výzkumu J. Kohoutka při obchvatu města na lokalitě OtrokoviceKvítkovice - Chmelín (2004) a při studiu eneolitické keramiky ve sbírkách zlínského muzea z téže lokality (1934) se podařilo identifikovat (překvapivě) nížinné sídliště jevišovické kultury, první svého druhu na levém břehu Moravy. Podobně datovaný materiál je k dispozici také z východních Čech. Nejbližší vazby prozrazuje keramika ke kultuře chamské v západních Čechách a ve východním Bavorsku a také k fázi Wachberg nejstarší jevišovické kultury na území Dolního Rakouska. Budeme tedy muset poněkud změnit dosud uznávanou mapu jevišovického osídlení již od jejích počátků.
\end{abstract}

\section{Klíčová slova}

východní Morava, mladší eneolit, jevišovická kultura, nížinné sídliště, keramika

\begin{abstract}
A lowland settlement of the Jevišovice Culture, the first of its kind on the left bank of the river Morava, was surprisingly identified among the finds from a rescue excavation conducted by J. Kohoutek during construction of a bypass road at Otrokovice-Kvítkovice - Chmelín (2004), and by studying Eneolithic pottery from the same locality which is stored in collections of the Zlín Museum (1934). Similarly dated material is also known from East Bohemia. This pottery exhibits closest relations to the Cham Culture in West Bohemia and East Bavaria and to the Wachberg phase of the earliest Jevišovice Culture on the territory of Lower Austria. With regard to these findings we will have to change a little the existing map of Jevišovice settlement since its origins already.
\end{abstract}

\section{Keywords}

East Moravia, Late Eneolithic, Jevišovice Culture, lowland settlement, pottery 


\section{1. Územní rozsah jevišovické kultury}

Kompaktním jádrem osídlení nositelů jevišovické kultury (JeK) jako součásti širšího mladoeneolitického kulturního komplexu je oblast jihozápadní Moravy a Brněnsko s plynulým přesahem na území Dolního Rakouska (západní část) až po úsek jižně od Dunaje, de facto až po předhůří SV Alp (obr. 1). Východním směrem osídlení obecně řídne. Při vymapování jevišovických nálezů na Slovensku je zjevná enkláva v oblasti Dudváhu a pravobřeží dolního toku řeky Váh (Šuteková 2008, obr. 18-19). Lokality v okolí Malých Karpat pak potvrzují předpokládané propojení s mateřskou oblastí jižní cestou spíše přes Bratislavskou bránu než přes jihovýchodní Moravu a Bílé Karpaty (cf. Peška 2000, 246-247; 2001). Na severu proniká JeK Boskovickou brázdou až na úroveň Svitávky a Velkých Opatovic. Není vyloučeno, že je to náznak postupu do východních Čech, kam mohla kultura pronikat povodním Svitavy a Loučné (Cerekvice nad Loučnou, Libčany, Proseč). Do budoucna nelze vyloučit menší enklávu trvalejšího osídlení ve východní části východních Čech (oblast Svitavy, Vysoké Mýto, Litomyšl, Choceň) třeba až po linii Pardubice - Hradec Králové. Keramickou mísu z Hradištka u Kolína (z řeky Labe), připisovanou jevišovické kultuře (Hrala 1959), musíme zatím hodnotit jako doklad kontaktů s domácí řivnáčskou populací, jak to dokládá keramika jevišovická a kultury kulovitých amfor na výšinném sídliště Denemark u Kutné Hory (Zápotocký - Zápotocká 2008, 174, 185-189). U Kolína je konec konců evidován i zásah bošácké kultury (Dobeš et al. 2013; Dobeš - Šumberová 2015).

Nejseverovýchodnější výspu jevišovického osídlení Moravy registrujeme na Kroměřížsku (Kroměříž-Miňůvky, Křenovice) v podobě velmi mladé (pozdní) JeK (Peška - Tajer 2009; Peška 2011). Jako ne zcela jasnou se ukazuje východní hranice moravské oikumeny, která je tradičně uváděna na řece Moravě v sousedství s kulturou bošáckou (cf. Pavelčk 1993; Peška 2013, 53, mapa 6). Nízký počet bošáckých nalezišt', nejasné osazení pravého břehu řeky Moravy zcela na jihovýchodě (Mikulčice, Břeclav-Pohansko), stejně jako průnik na Hradecko (Vokolek 1982; Vokolek - Zápotocký 1990; Kalferst - Prostřednik 1998; 2000; Kalferst 2001), nebo již zmíněné nálezy z obchvatu Kolína (Dobeš et al. 2013; Dobeš - Šumberová 2015), situaci poněkud komplikují. Nálezy spojované s JeK v blízkosti řeky Moravy známe již nějakou dobu. Kromě již jmenovaných nížinných sídlišt a kostrového hrobu z Křenovic a Miňůvek jde o výšinné sídliště Buchlovice - Modla s údajným jevišovickým osídlením (Čižmář 2004, 103-104) a ojedinělý nález kamenného sekeromlatu typu HalfingLinz nedaleko Bzence (Bzenec-Přívoz: Šebela 1989). Dosavadní představu o neosídlení levého (východního) břehu Moravy lidem JeK definitivně boří předložené sídlištní nálezy z OtrokovicKvítkovic a nejspíše také dosud nezpracovaný a tím pádem obsahově ne zcela vymezený nálezový kontext ze sídliště Hulín-Pravčice $1 \mathrm{v}$ trati U obrázku, který se stane předmětem budoucí samostatné publikace.

\section{Sídlištní nálezy z Otrokovic - Kvítkovic}

V rámci provádění záchranného archeologického výzkumu (vedoucí J. Kohoutek, ÚAPP Brno) na lokalitě Otrokovice-Kvítkovice, trat Chmelín v roce 2004 v souvislosti se stavbou SV obchvatu města (přeložka silnice I/49) bylo mimo jiné zachyceno polykulturní osídlení od neolitu až po dobu laténskou a středověk (obr. 3). Výjimečný obsah poskytl objekt č. 516, jehož analýza je předmětem této stati.

Ve sbírce Muzea JV Moravy ve Zlíně upoutala moji pozornost větší hrncovitá nádoba a v ní několik střepů opět z Otrokovic-Kvítko- 


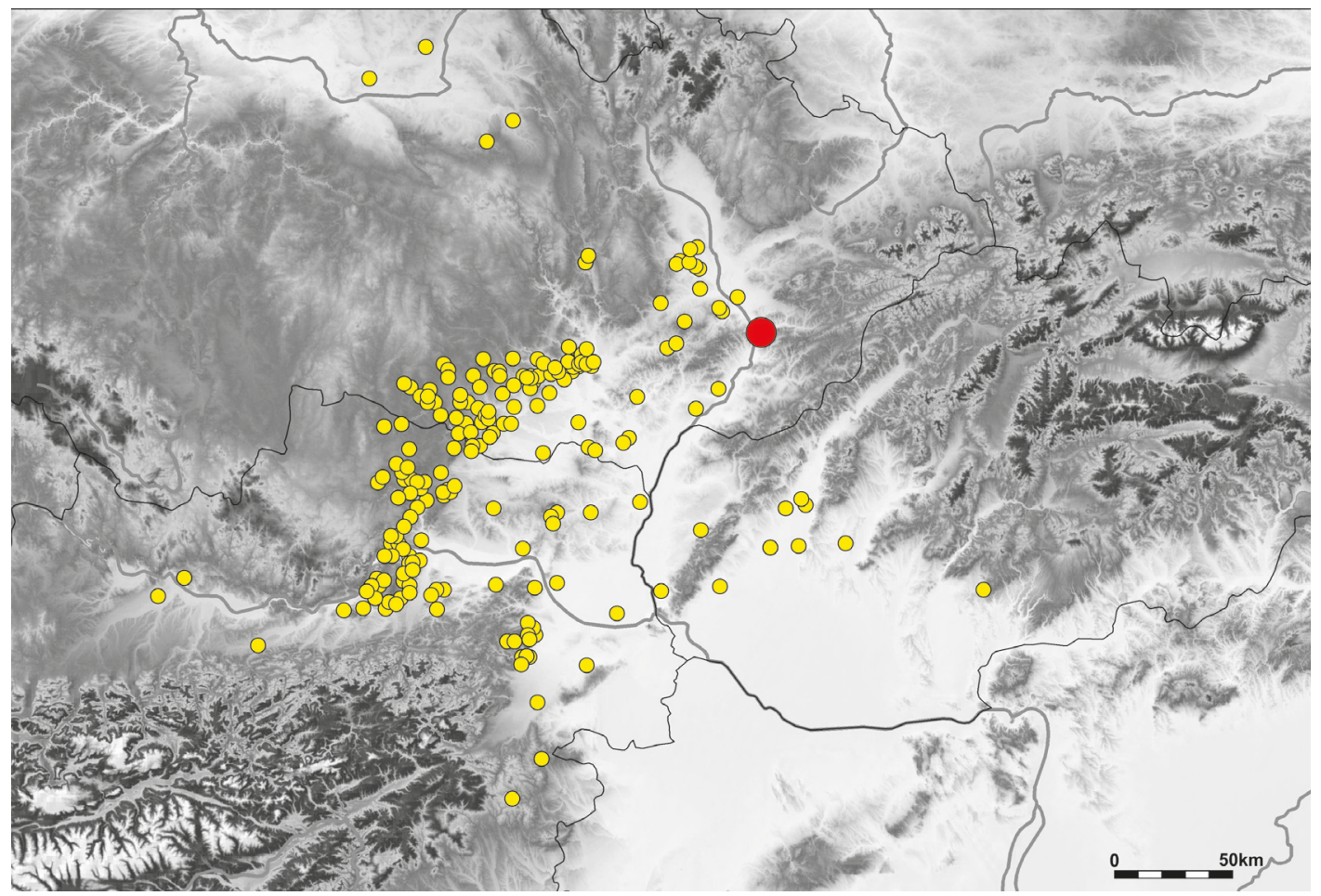

Obr. 1. Mapa rozšíření jevišovické kultury na Moravě, v Dolním Rakousku, JZ Slovensku a ve východních Čechách. Mapa K. Pluskalová.

Fig. 1. Distribution map of Jevišovice Culture in Moravia, Lower Austria, SW Slovakia and East Bohemia. Map by K. Pluskalová.

vic. S pomocí muzejního archeologa v osobě J. Langové se podařilo dohledat, že nádoba (inv.č. 6509) byla nalezena 18. září 1934 při stavbě silnice ze „Zlína do Batova“ na parcele č. 1043/4 v trati Chmelín! Části nádoby ve zlomcích vyzvedl J. Doležel (předák na stavbě) a V. Bachmánek (jednatel Muzejního a archeologického spolku v Napajedlích). Oba spolupracovali s I. L. Červinkou, který jim nádobu určil jako jevišovickou, nebo-li jako „kulturu nákolních staveb“! Díky vzájemné podobnosti obou souborů můžeme s velkou mírou pravděpodobnosti usuzovat na shodnou kulturní př́slušnost a na zachycenou nížinnou osadu nositelů jevišovické kultury z počátku jejího vývoje.

\section{Naleziště}

Trat Chmelín, v minulosti nazývaná také Chmeliny, ležící východně od okraje zástavby Kvítkovic (místní část města Otrokovic), patří nepochybně k nejbohatším a nejvýznamnějším polykulturním nalezištím v širším rámci zlínského regionu. První nálezy archeologické povahy byly v těchto místech zjištěny v letech 1934-1935, a to v souvislosti se stavbou nové komunikace spojující Zlín s Otrokovicemi (dnešní 1/49), kdy zde byly narušeny kulturní vrstvy a četné objekty z pravěkého období, které tehdy částečně prozkoumali členové napajedelského muzejního spolku, zejména jednatel spolku V. Bachmánek (Kohoutek 1996, 560). 


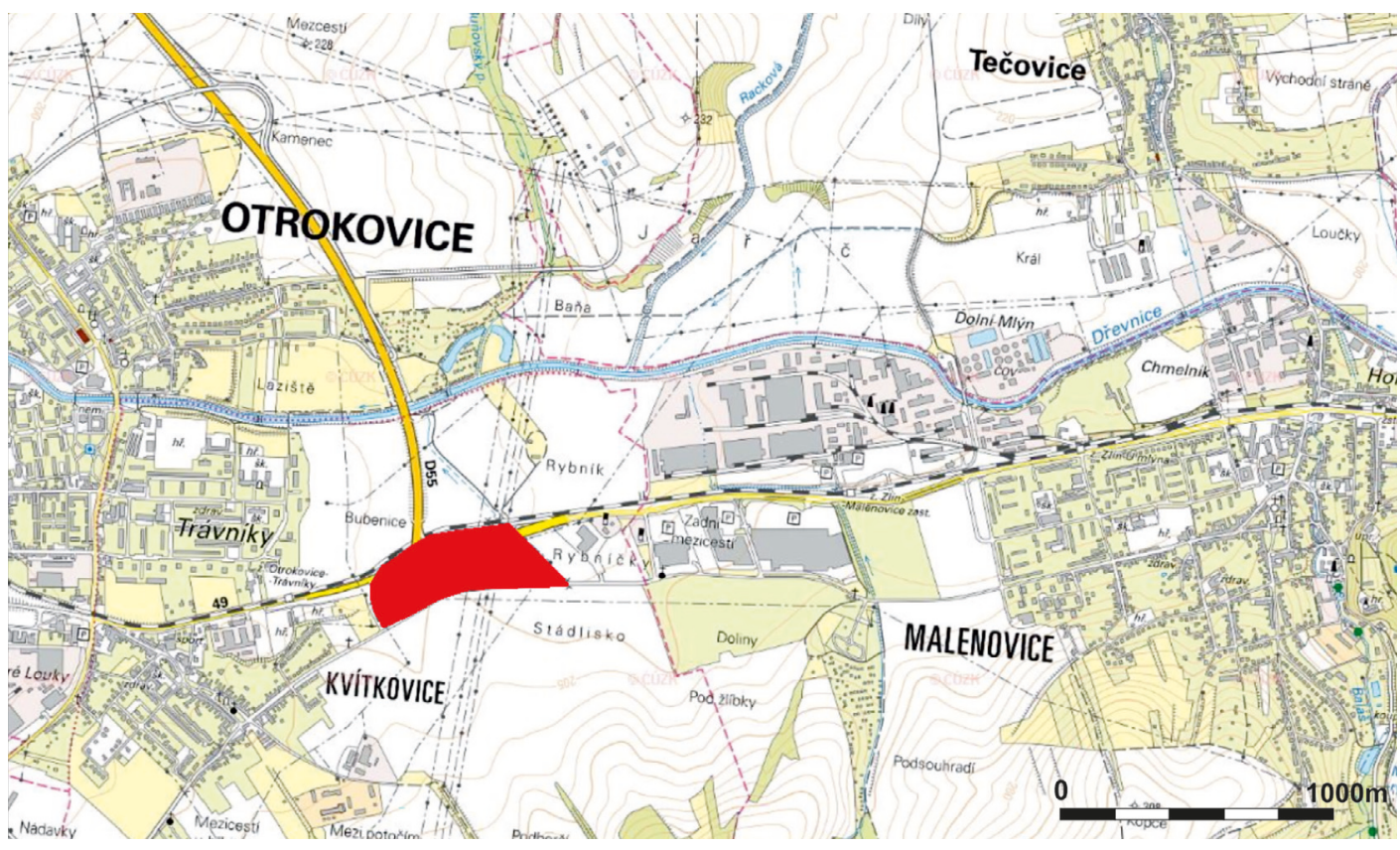

Obr. 2. Otrokovice-Kvítkovice - Chmelín 2004. Poloha zkoumané lokality (červeně) v mapě 1:10 000. Mapa K. Pluskalová.

Fig. 2. Otrokovice-Kvítkovice - Chmelín 2004. Position of the examined site (red) in a map 1:10 000. Map by K. Pluskalová.

Další nálezy zde pak byly získány především povrchovou prospekcí v padesátých a šedesátých letech minulého století (V. Dohnal, J. Očenášek). V roce 2000 při realizaci rekonstrukce plynovodu bylo zjištěno celkem 10 zahloubených sídlištních objektů, patřících jednak kultuře s lineární keramikou a jednak do okruhu kultur popelnicových polí (Výroční zpráva ÚAPP Brno 2000, 17). Dosud bylo v těchto místech registrováno osídlení od neolitu (LnK, MMK), eneolit (badenská kultura), starší a mladší dobu bronzovou až po kulturu laténskou (Kohoutek Langová 2001).

Výzkum v roce 2004 potvrdil a zpřesnil poznatky o dlouhodobém osídlení naleziště od neolitu: kultura s lineární keramikou a moravskou malovanou keramikou, eneolitu: jordanovská, jevišovická kultura, přes starší dobu bronzovou: nitranská a věteřovská kultura, mladší a pozdní dobu bronzovou a dobu halštatskou: lužická, slezská a platěnická kultura, dobu laténskou až po 15. století (Kohoutek 2006; Kohoutek - Parma 2006).

Lokalita Chmelín je situována na výrazném terénním hřbetu táhnoucím se delší osou zhruba ve směru západ - východ nad údolní nivou levobřeží řeky Dřevnice (jedná se víceméně o říční terasu a současně severní výběžek západního ukončení Vizovické vrchoviny). Nadmořská výška lokality se pohybuje v rozpětí od 195 do $200 \mathrm{~m}$ (obr. 2). V minulosti byly východně pod návrším Chmelína rybníky, podle katastrální mapy Kvítkovic z roku 1829 je patrné, že severní okraj terénní vlny se blížil meandrujícímu toku řeky Dřevnice (tato severní část byla zničena právě při stavbě železnice Otrokovice - Vizovice na konci 19. století a již výše zmíně- 


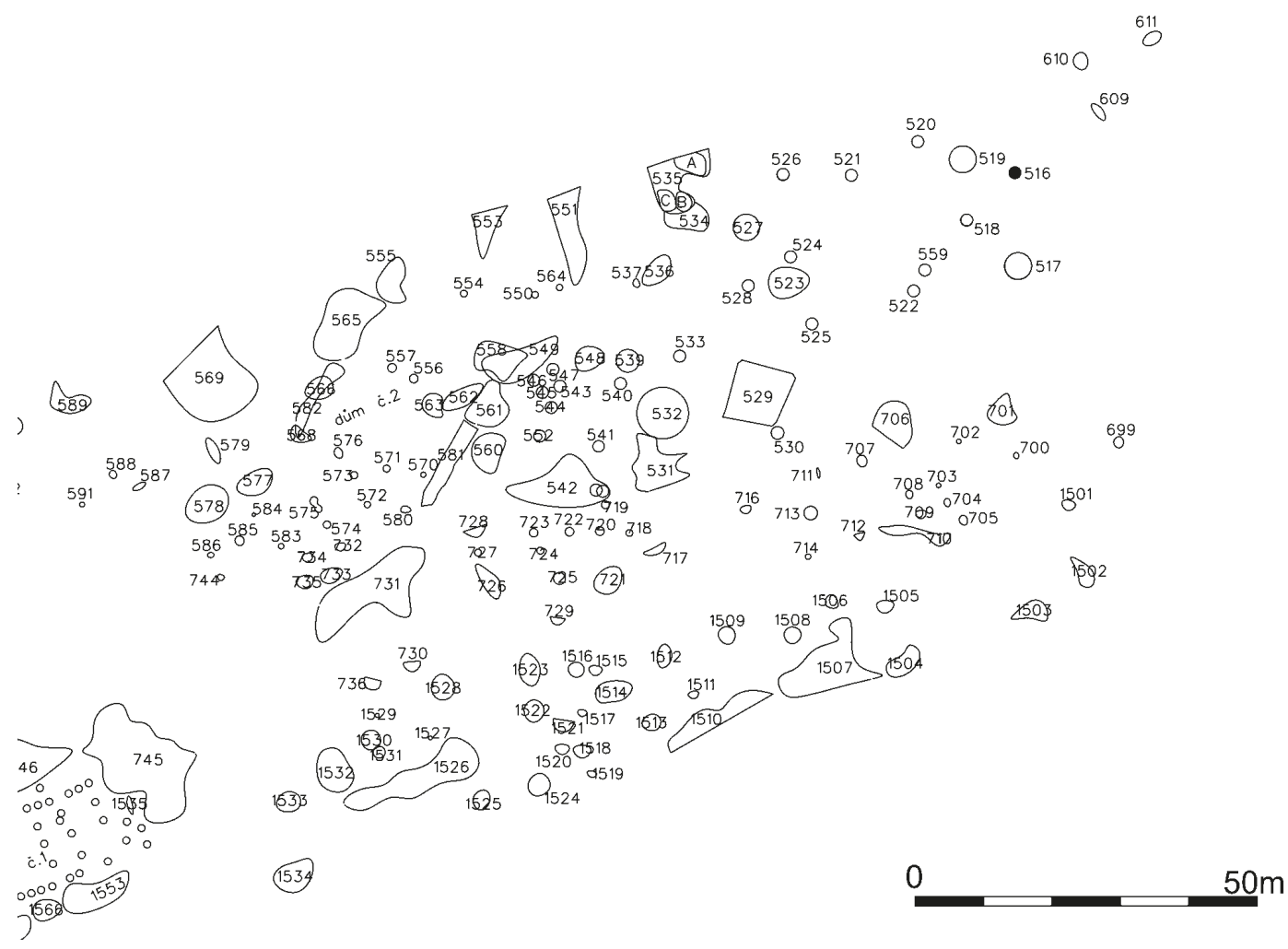

Obr. 3. Otrokovice-Kvítkovice - Chmelín 2004. Výřez celkového plánu zkoumaných ploch s vyznačením objektu JeK (č. 516 - černá barva). Plán ing. Koplík, úprava P. Grenar.

Fig. 3. Otrokovice-Kvítkovice - Chmelín 2004. Cut-out from a general plan of examined areas with highlighted position of a feature of Jevišovice Culture (No. 516 - black colour). Plan by Ing. Koplík, edited by P. Grenar.

nou stavbou Batovy silnice v letech 1934-1935). Geologickým podložím jsou vrstvy flyše zlínského souvrství račanské jednotky (střední eocén - spodní oligocén), charakteristické stř́ídáním zčásti vápnitých jílovců a glaukonitických pískovců. Nad tímto podložím samotné lokality se uchovaly místy (především z východní strany) vrstvy spraše, které jsou v oblasti Napajedelské brány poměrně časté.

\subsection{Jáma č. 516}

Sledovaný materiál pochází z objektu č. 516, což je sídlištní jáma nepravidelně oválného půdory- su s lehce prohnutým dnem a vakovitým průřezem (obr. 4, 5) s rozměry $190 \times 160 \times 65 \mathrm{~cm}$, vyplněná černou písčitou hlínou. Nacházela se v těsném sousedství dalších pravěkých jam při samém SV okraji prozkoumané plochy (obr. 3), takže další objekty mimo zkoumanou plochu nelze a priori zcela vyloučit. Na jejím dně se v SV sektoru nacházelo ve zlomcích několik rekonstruovatelných nádob (2 mísy, 2 hrnce a kónická nádobka) a další fragmenty dalších hrncovitých nebo zásobnicovitých nádob (obr. 8). Soubor uzavírají dvě blíže neurčené kamenné podložky se stopami používání (min. jedna ve funkci zrnotěrky). 


\subsubsection{Popis vybraného materiálu:}

1. Skoro celá hrncovitá nádoba s lehce prohnutým hrdlem esovité profilace s náznakem odsazení vyššího těla se zúženým spodkem a lehce odsazeným rovným dnem. Slabě zesílený okraj je po obvodu přesekáván, stejné provedení má jediná obvodová linie kolmých záseků těsně nad maximální výdutí. Materiál jemnozrnný, vně světle hnědý, uvnitř tmavohnědý upravený povrch. Průměr okraje 250; průměr max. výduti 292; průměr dna 130; výška 306 mm. M Zlín 129/03-117/1. (obr. 6:5)

2. Torzo lehce esovitě profilovaného hrnce. Okraj přesekáván linií kolmých záseků, hrdlo odděleno od těla podobnou přesekávanou linií s náznakem plastické lišty na plecích nádoby nad maximální výdutí. Hrdlo vyhlazeno, od linie záseků je tělo zdrsněno. Materiál jemnozrnný, světle hnědý povrch. Průměr okraje 140; průměr maximální výduti 161; zach. výška 141 mm. M Zlín 129/03-117/2. (obr. 5:6)

3. Část nálevkovité ostře profilované mísy s lomeným tělem. Dno slabě vklopené. Materiál jemnozrnný, šedohnědý se světlými skvrnami, upravený povrch. Průměr okraje 250; průměr výduti 215; průměr dna 74, výška 121 mm. M Zlín 129/03-117/3. (obr. 5:7)

4. Zlomky hlubší esovitě profilované mísy (teriny) s přesekávaným zaobleným okrajem. Prohnuté vyhlazené hrdlo přechází v oblé zdrsněné tělo oddělené plastickou přesekávanou lištou na rozhraní hrdla a plecí. Materiál jemnozrnný, vně světle hnědý, uvnitř černý upravený povrch. M Zlín 129/03$117 / 5,10,12$. (obr. 6:2)

5. Fragment hrnce lehce esovité profilace s mírně zesíleným okrajem opatřeným přesekáváním. Na rozhraní hrdla a těla obvodová linie záseků. Hrdlo vyhlazeno, tělo zdrsněno. Materiál jemnozrnný, světle hnědý povrch. M Zlín 129/03-8, 13, 16 (obr. 6:1)
6. Dno a střepy z těla větší zásobnicové nádoby s okrajem opatřeným plastickou protlačovanou lištou. Dno mírně vklopené. Tělo nádoby zdrsněno po celém povrchu. Materiál jemnozrnný, vně světle hnědý, uvnitř černý upravený povrch. M Zlín 129/03$117 / 6,17,20$. (obr. 5:1-4)

7. Nálevkovitá mísa s lomeným tělem. Dno slabě vklopené. Na rozhraní hrdla a těla vedle sebe dvě tunelovitá ouška. Materiál jemnozrnný, šedohnědý hlazený povrch. V keramickém těstě patrné červené hrudky. Průměr okraje 230; průměr výduti 201; průměr dna 80; výška 137 mm. M Zlín 129/03-117/18. (obr. 6:4)

8. Širší kónická nádobka (čerpák?) s rovným dnem. Doplněno sádrou. Materiál jemnozrnný, hnědý hlazený povrch. Průměr okraje 100; průměr dna 50; výška $112 \mathrm{~mm}$. M Zlín 129/03-117/29. (obr. 5:5)

9. Dno masivnější kónické nádoby. Dno rovné. Materiál jemnozrnný, vně světle hnědý, uvnitř černý upravený povrch. Průměr dna 90 mm. M Zlín 129/03-117/30. (obr. 6:3)

\subsection{Chmelín 1934}

Jak už uvedeno výše jedná se o starší nález z narušeného sídliště. Na základě podobnosti keramického materiálu, včetně technologie výroby, výpalu a úpravy povrchu, lze usuzovat na sounáležitost jak velké zásobnice, tak i střepů v ní uložených (obr. 7, 9, 10). Materiál tedy nejspíše pochází z jednoho objektu a spolu s výše uvedeným objektem 516 představuje část osady lidu JeK na východ od řeky Moravy.

\subsubsection{Popis vybraného materiálu:}

1. Velká hrncovitá nádoba výraznější esovité profilace s kónicky prohnutým hrdlem 


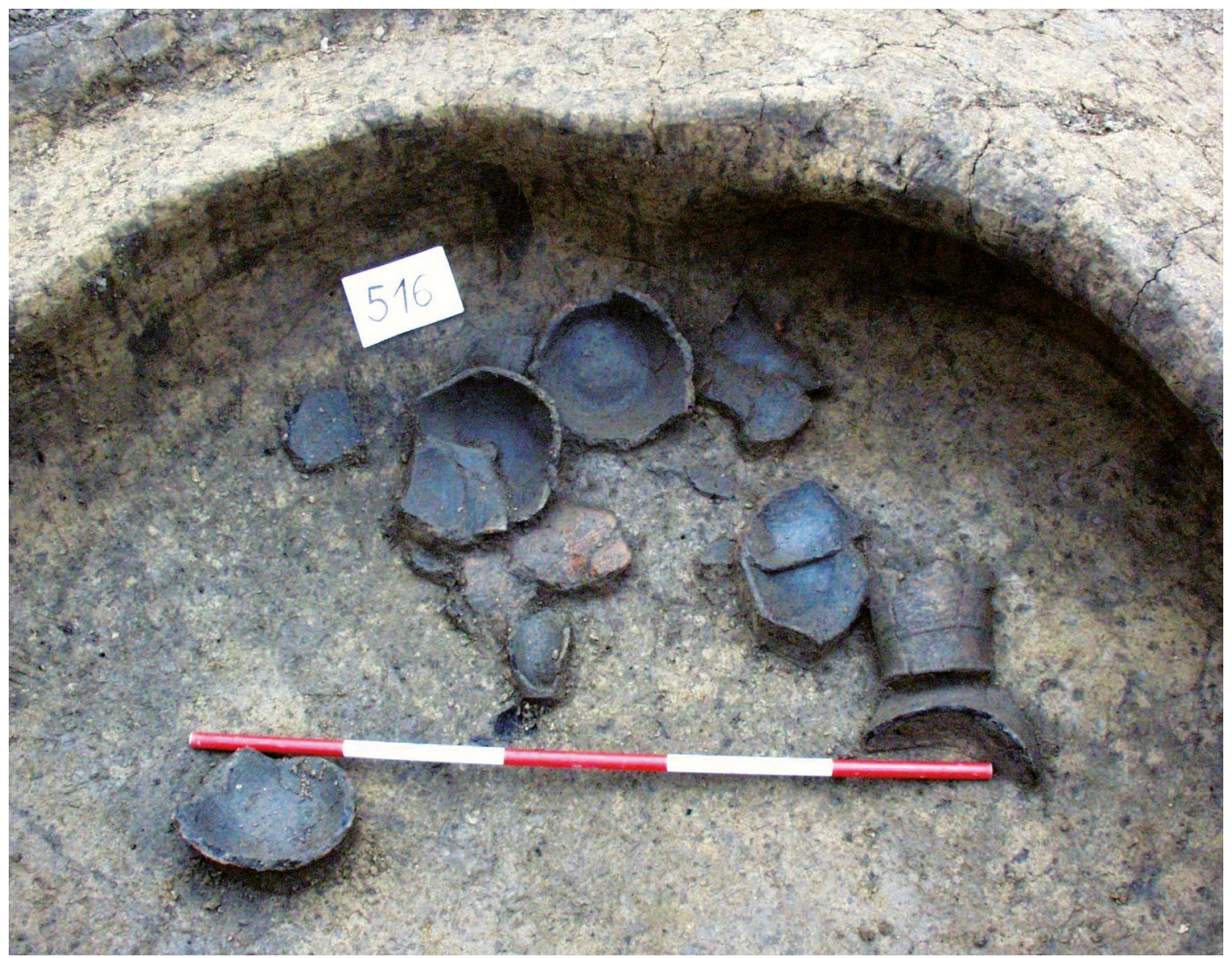

Obr. 4. Otrokovice-Kvítkovice - Chmelín 2004. Jáma č. 516 s nálezy kolekce keramiky. Foto J. Langová.

Fig. 4. Otrokovice-Kvítkovice - Chmelín 2004. Pit No. 516 with a collection of ceramic finds. Photo by J. Langová.

a náznakem lehce odsazených plecí. Dno rovné. Lehce vyhnutý okraj je zdoben přesekáváním. Shodná trojitá přesekávaná obvodová linie (vystupuje lehce plasticky) zdobí plece těsně nad maximální výdutí. Materiál jemnozrnný, světle- až žlutohnědý hruběji hlazený povrch. Průměr okraje 250; průměr max. výduti 410; průměr dna 120; výška $470 \mathrm{~mm}$ M Zlín 6509. (obr. 7:3)
2. Zlomek okraje velké hrncovité nádoby s prohnutým hrdlem. Těsně pod okrajem probíhá plastická přesekávaná lišta. Plece zdobí rozeklaná dvojice přesekávaných lišt (dvojitá „V“ lišta). Materiál jemnozrnný, světle hnědý upravený povrch. M Zlín bez inv.č. (obr. 7:2)

3. Zlomek okraje hrncovité nádoby s prohnutým hrdlem a přesekávaným okrajem. Materiál jemnozrnný, vně světle hnědý, uvnitř tmavošedý upravený povrch. M Zlín bez inv.č. (obr. 7:1) 


\section{Analýza keramického inventáře}

Na sídlištní poměry relativně bohatý a typologicky pestrý keramický inventář jámy 516 je zastoupen hrncovitými nádobami s presekávanými okraji a obvodovými liniemi (obr. 5:6; 6:1,5), někdy se zdrsněným tělem, stejně upravenou hlubší mísou (obr. 6:2), fragmenty zásobnice (obr. 5:1-4), dvojicí nálevkovitých mís (obr. 5:7; 6:4), včetně páru širších čerpáků s rovným dnem (obr. 5:5; 6:3). Typologická, technologická i dekorativní shoda především rozměrné hrncovité nádoby, kterou lze však stejně dobře klasifikovat jako zásobnici či bezuchou amforu (obr. 7:3) z výzkumu v roce 1934, nás utvrzuje ve shodě kulturního zařazení celého souboru keramiky. Pracujeme tedy se sídlištním materiálem minimálně ze dvou objektů, jejichž vzájemná poloha však dnes již není rekonstruovatelná. Přestože se původně zdálo, že nížinné osady nebudou patřit $\mathrm{k}$ typickým projevům nositelů jevišovické kultury, výzkumy posledních let ukazují, že tomu tak nebude, nebot plošné záchranné výzkumy poslední doby zachycují stále častěji právě nížinné, někdy velmi rozsáhlé osady (Křenovice, Kroměříž-Miňůvky, Mašovice, Brno- Starý a Nový Lískovec a Bohunice, Modřice). Ty však zatím zůstávají většinou bez odborného vyhodnocení, a tak se o ně nelze opřít. $\mathrm{S}$ výjimkou lokality Mašovice - Pšeničné (Čižmář 2002, obr. 5; 2003) se zdá, že ostatní náleží až mladšímu/ nejmladšímu vývoji JeK na Moravě (cf. Peška 2011; 2013, 46, tab. 3).

Nejhojněji zastoupeným keramickým typem na jevišovických sídlištích jsou hrnce a hrncovité tvary. Jejich charakteristika ve formě více méně esovité profilace, přesekávání okrajů, plastické lišty nebo řady záseků/vpichů na rozhraní hrdla a plecí (těla) se zdrsněním povrchu těla nádoby (včetně slámování) se plně uplatnila i na naší malé kolekci. Se zdrsněním povrchu těla nádoby, tak charakteristickém znaku mladoeneolitické keramiky obecně, se setkáváme např. již u IV. sídelního horizontu ve Hlinsku (Pavelčik 2004, obr. 10:4; 11:1), který je tradičně spojován s klasickou fází badenské kultury.

Velký hrnec/zásobnice/bezuchá amfora z roku 1934 se liší od největšího hrnce z jámy 516 jen v detailech (obr. 7:3; 6:5), když na větší nádobě je aplikována trojice lehce plasticky vystupujících linií záseků. $\mathrm{S}$ takovou keramikou se setkáváme především na chamských sídlištích západních Čech (Bzí - Velká skála: Jilková 1957, obr. 3:3; Prostřednik 2001, obr. 51:2; Zdemyslice - Polánka: John 2010, obr. XIII) nebo východního Bavorska (Burger 1988, Abb. 4), stejně jako ve fázi (facie) Wachberg JeK v Dolním Rakousku (Ruttkay 2001, Abb. 1 Töpfe A3 a A5). Do této oblasti vůbec směřuje převaha analogií pro námi zkoumaný materiál. Tektonika nádob JeK na Moravě, včetně nejstarších projevů na úrovni Grešlové Mýto, je poněkud odlišná (MedunováBenešová 1973, Taf. 5:3). Přesekávaný okraj nese také střep z jiné hrncovité nádoby z objektu z r. 1934 (obr. 7:1) a zlomek velké nádoby s plastickou přesekávanou lištou při okraji z téhož souboru (obr. 7:2). Jedná se o velmi starobylý výzdobný dekor eneolitických nádob minimálně od doby kultury nálevkovitých pohárů (KNP).

Linii záseků nebo jednoduchou, dvojitou, trojitou či ještě vícenásobnou plastickou lištu nacházíme $\mathrm{v}$ různých obměnách na keramických tvarech (hrnce, mísy, amfory) chamské kultury (John 2010, obr. 85:14,16; 118:7; Burger 1988, Taf. 12:1; 13:1,7; 28:1; 80:9 ad.), kde je tato výzdoba velmi hojná a vyskytuje se i na jiných typech nádob (Burger 1988, Taf. 83:6; 100:4). O něco menší frekvenci můžeme sledovat na sídlišti Wachberg (Ruttkay 2001, Abb. 1), kde je také časté „nalepení“ protlačovaných nebo přesekávaných lišt těsně při okraji (připomíná hrnec z obj. 516: obr. 5:6), může jít o dědictví badenské kultury. Lišta na okraji, příp. jeho zesílení tímto způsobem není cizí napřr. ani skupině Nyírség v SV části Mad’arska (Kalicz 1968, Taf. XXXI:1). Výzdobné schéma dvou lišt 

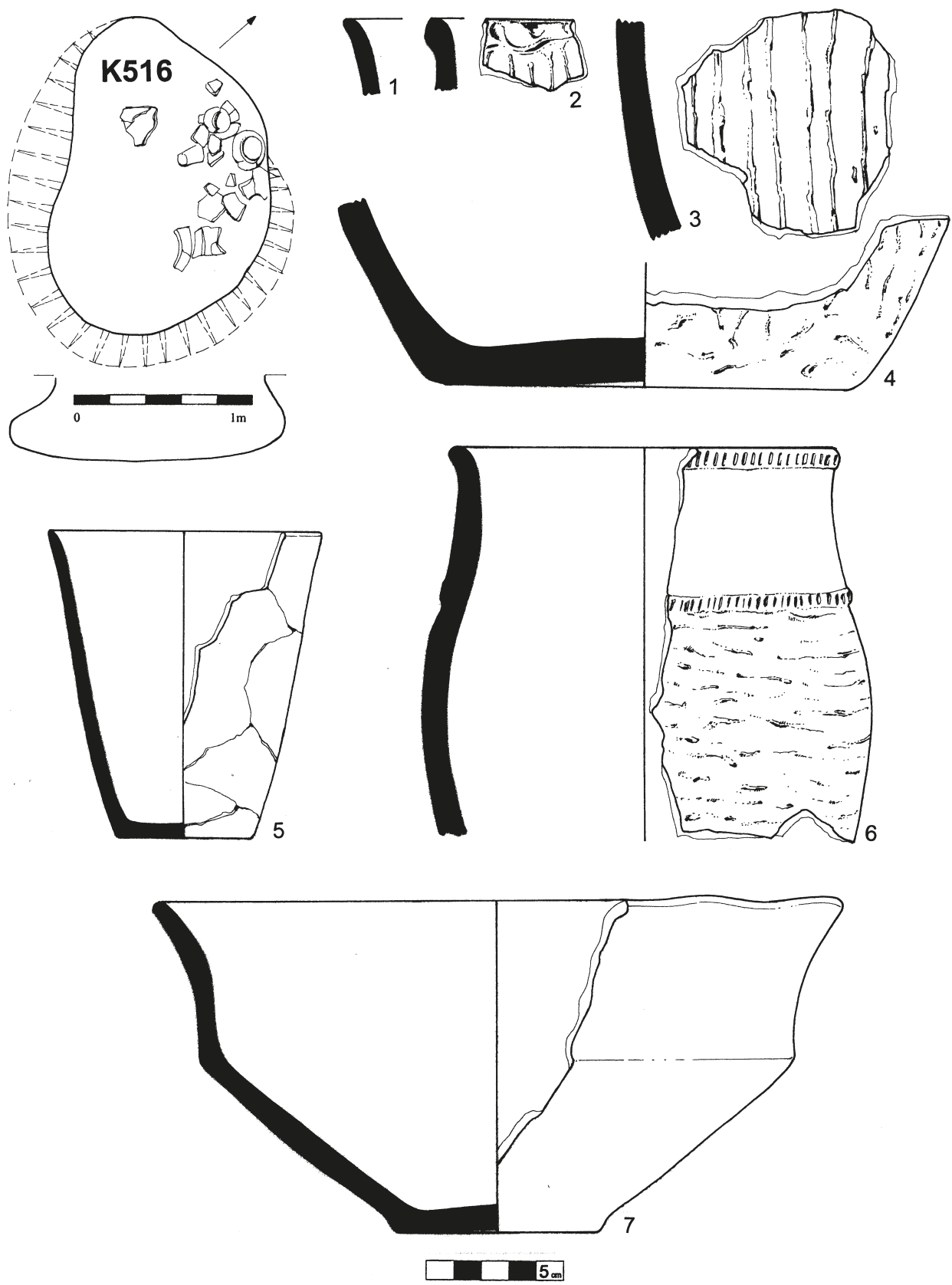

Obr. 5. Otrokovice-Kvítkovice - Chmelín 2004. Keramické nálezy z jámy č. 516. Kresby A. Pešková.

Fig. 5. Otrokovice-Kvítkovice - Chmelín 2004. Ceramic finds from pit No. 516. Drawings by A. Pešková. 


\section{K516}
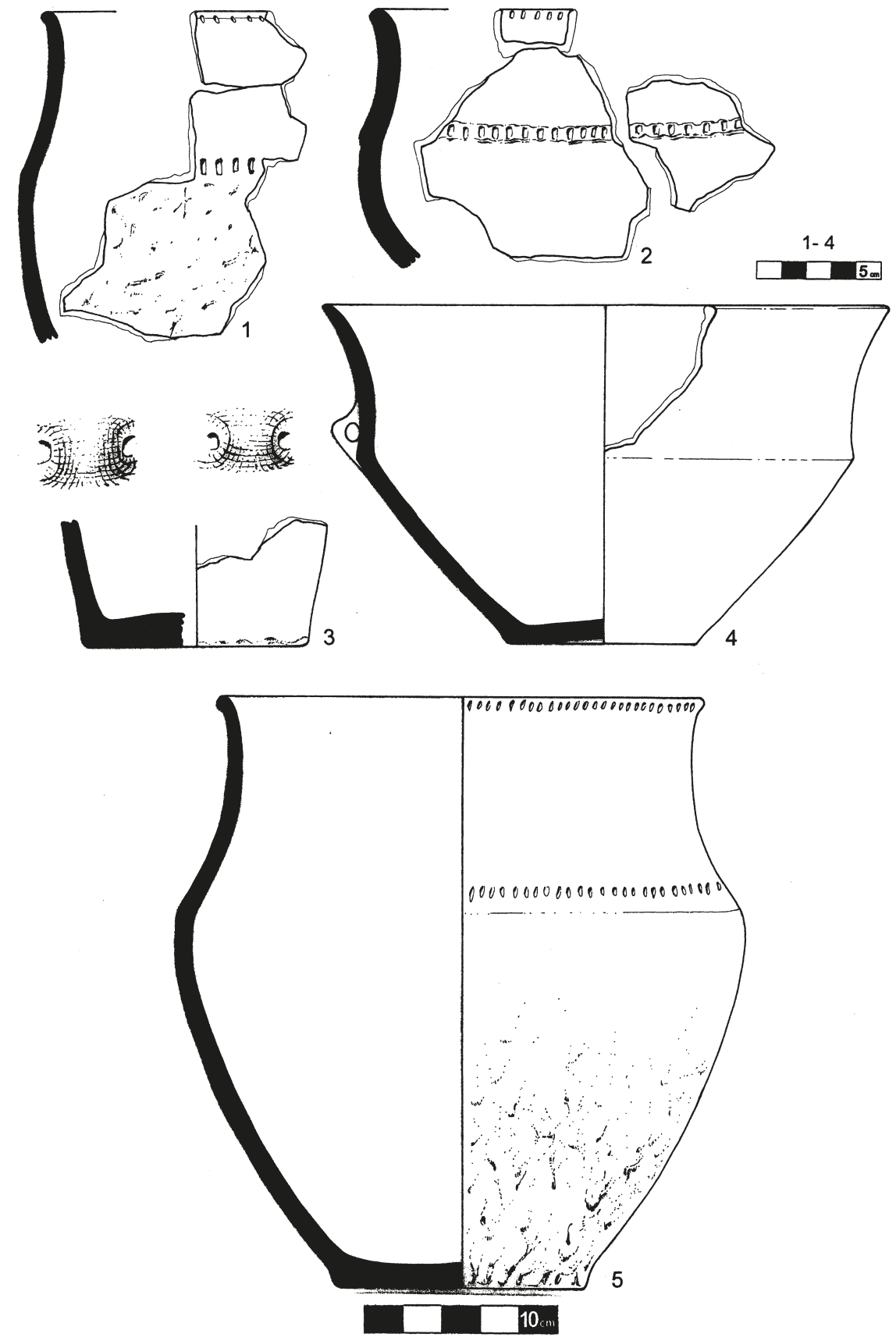

Obr. 6. Otrokovice-Kvítkovice - Chmelín 2004. Keramické nálezy z jámy č. 516.

Fig. 6. Otrokovice-Kvítkovice - Chmelín 2004. Ceramic finds from pit No. 516. 
se objeví i na pokročilejší dolnorakouské jevišovické keramice facies Spielberg (Krenn-Leeb 1999, Abb. 3) nebo na amforách velmi pokročilé resp. pozdní badenské keramiky skupiny Zesławice-Pleszów a Mogiła (Zastawny 2011, Ryc. 10:1-4) v doprovodu slámovaných hrnců a hrotitých čerpáků. Plastický motiv více lišt nad sebou je relativně často aplikován na keramice vyspělé kultury Coțofeni III v Rumunsku, časově zhruba na úrovni JeK a Bošáca (Ciugudean 2000, Pl. 89:15,16), kde se v náplni objevují i další ,jevišovické“ tvary jako jsou rendlíky (ty např. i v lublaňské kultuře na lokalitě Ig) a mísy se zataženým okrajem. Plastická výzdoba nádob pak pokračuje i ve skupině Livezile a dále na keramice doby bronzové.

Plece větší nádoby z r. 1934 zdobí zdvojená plastická přesekávaná lišta do tvaru písmene „V“ (obr. 7:2; 10), která nás svými protějšky zavádí de facto do stejného kulturního prostředí zejména kultury chamské (John 2010, obr. 150:1; Burger 1988, Taf. 85:3; 101:4; 102:16,17). V-lišta se na domácí jevišovické keramice prakticky neobjevuje, a pokud vůbec, tak v pozměněné podobě (obrácena dolů a většinou plná), avšak výhradně v kontextu keramiky ovlivněné z chamského prostředí (Grešlové Mýto). V zásadě však jde o starý eneolitický plastický motiv (Koštuřrı 2007, obr. 66:163, Tab. 16:12; Šmíd Prichystal 2015, kód 1907, 2235).

Ve fragmentech dochovaná zásobnicová nádoba z jámy 516 má při okraji protlačovanou plastickou lištu a její celý povrch od okraje až po dno je zdrsněný (obr. 5:1-4), což je jev na mladoeneolitické keramice takřka nevídaný, nebot̉ zde je v jasné převaze zdrsněné tělo nádoby oddělené od hlazeného hrdla. Jen v několika případech dosahuje zdrsnění těsně k plastické liště na okraji nebo až k okraji nádoby (Medunová-Benešová 1973, Taf. 20:5,6; 21:6,9; 22:5-8; 23:1).

Na hlubší terinovité míse z jámy 516 je opět aplikována myšlenka dvou výzdobných prvků: přesekávání okraje a plastické přesekávané nebo protlačované lišty na rozhraní hrdla a plecí (obr. 6:2), velice oblíbená v chamské oblasti. V JeK je poněkud řidší a její častější aplikace vycházejí až na mladší období, včetně hlubokých profilovaných mís (Jevišovice B: Medunová-Benešová 1972, Taf. 25:1-3; 36:1,3; 110:11). Dost výjimečná je tato kombinace výzdoby na klasické badenské keramice (např. Banner 1956, Taf. LIII:5) a zcela ojedinělá u bolerázské (Horváth 2012, Fig. 12:2).

Nalezený keramický soubor doplňují (kromě řady drobných střepů sídlištní keramiky) dvě nálevkovité mísy, resp. jejich větší části. V jednom případě se dochovala dvojice tunelovitých oušek umístěná na lomu hrdla a těla mísy (obr. 6:4). Uvedený tvar má nejen v našem eneolitu velmi starobylou a bohatou tradici. Pro širší a nižší mísu (obr. 5:7) jsme schopni najít protějšky de facto již od staršího eneolitu v kultuře nálevkovitých pohárů (Šmíd 2003, obr. 31; 38; Tab. 10:3; 14:3), přes Boleráz (Brno-Líšeň I: Medunová-Benešová 1964, obr. 31:6,7), Jevišovice vrstvy C2 i C1 (Medunová-Benešová 1981, Taf. 8; 70), Ohrozim (Medunová-Benešová 1967, obr. $11: 1 ; 12: 4,6,12)$, klasickou badenskou kulturu (Furholt 2009, Taf. 22:8). Zastoupena je také ve fázích Wachberg a Spielberg JeK v Dolním Rakousku (Ruttkay 2001, Abb. 2 C1, Schicht 2; C2 Schicht 2; Krenn-Leeb 1999, Abb. 6:C2a), v moravské JeK spíše sporadicky (Svitávka-Hradisko: Štrof 1994, obr. 8:4). Výjimkou nejsou ani v chamské kultuře, kde např. na sídlišti Dobl se objevují ve velkém počtu (Burger 1988, Taf. 20:1; 22:4 etc.) a nechybí ani v západních Čechách (John 2010, obr. VIII:2).

Vyšší mísa s dvojicí oušek (obr. 6:4) má dost přesnou analogii v obj. 6 klasické badenské kultury v Reichersdorfu (Sachsse 2010, Taf. 140:9) nebo v jámě s kostrou ze sídliště v Chlabě na Slovensku s jedním uchem a linií vpichů na lomu hrdla a těla (Nevizánsky 2001, tab. I:4). Mísa z objektu 397 téže kultury z moravských 

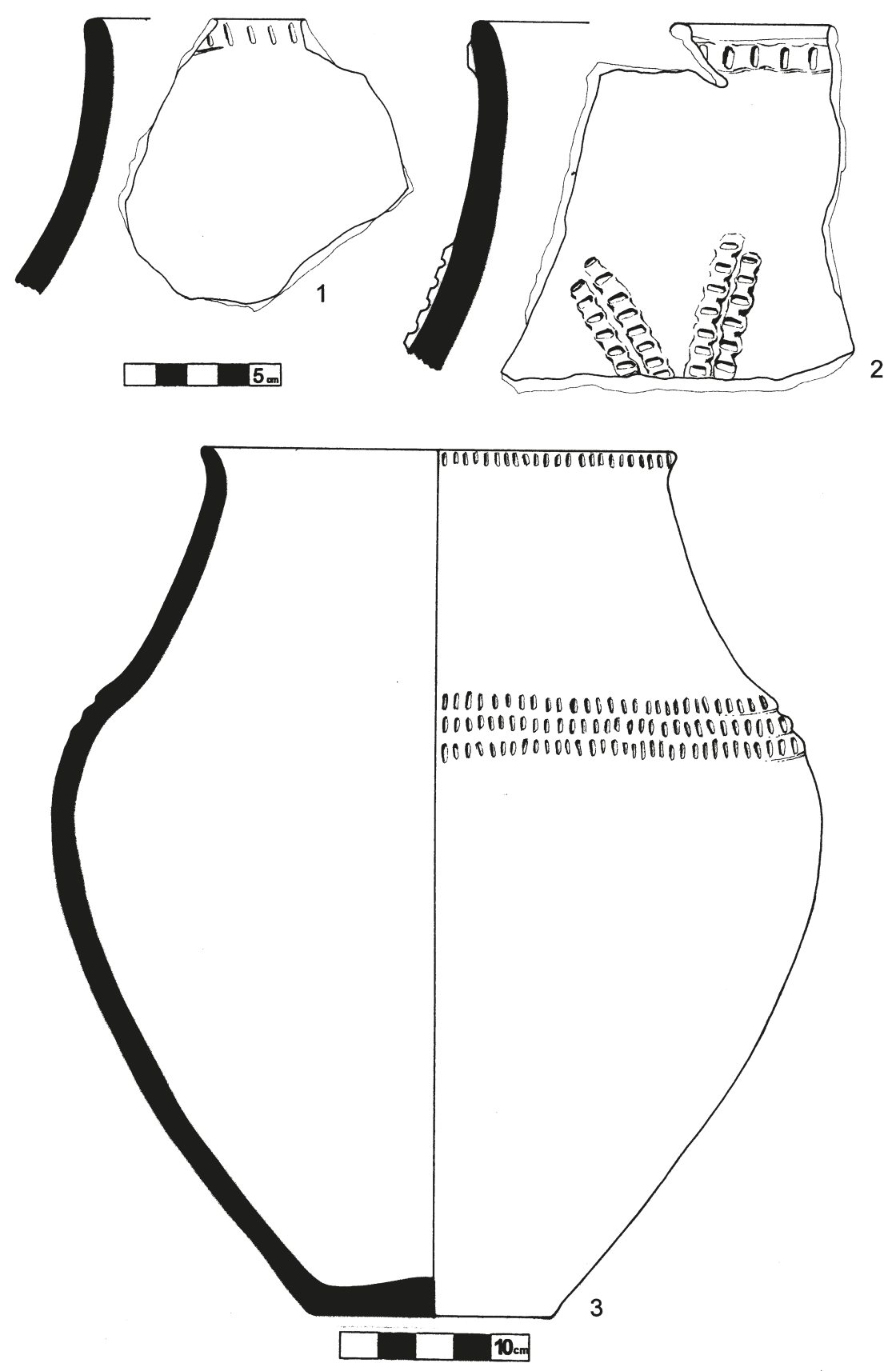

Obr. 7. Otrokovice-Kvítkovice - Chmelín 1934. Zásobnice a střepy zdobených nádob z jámy z roku 1934 (uloženo MZlín).

Fig. 7. Otrokovice-Kvítkovice - Chmelín 1934. Storage jars and fragments of decorated vessels from a pit excavated in 1934 (stored in Zlín Museum). 


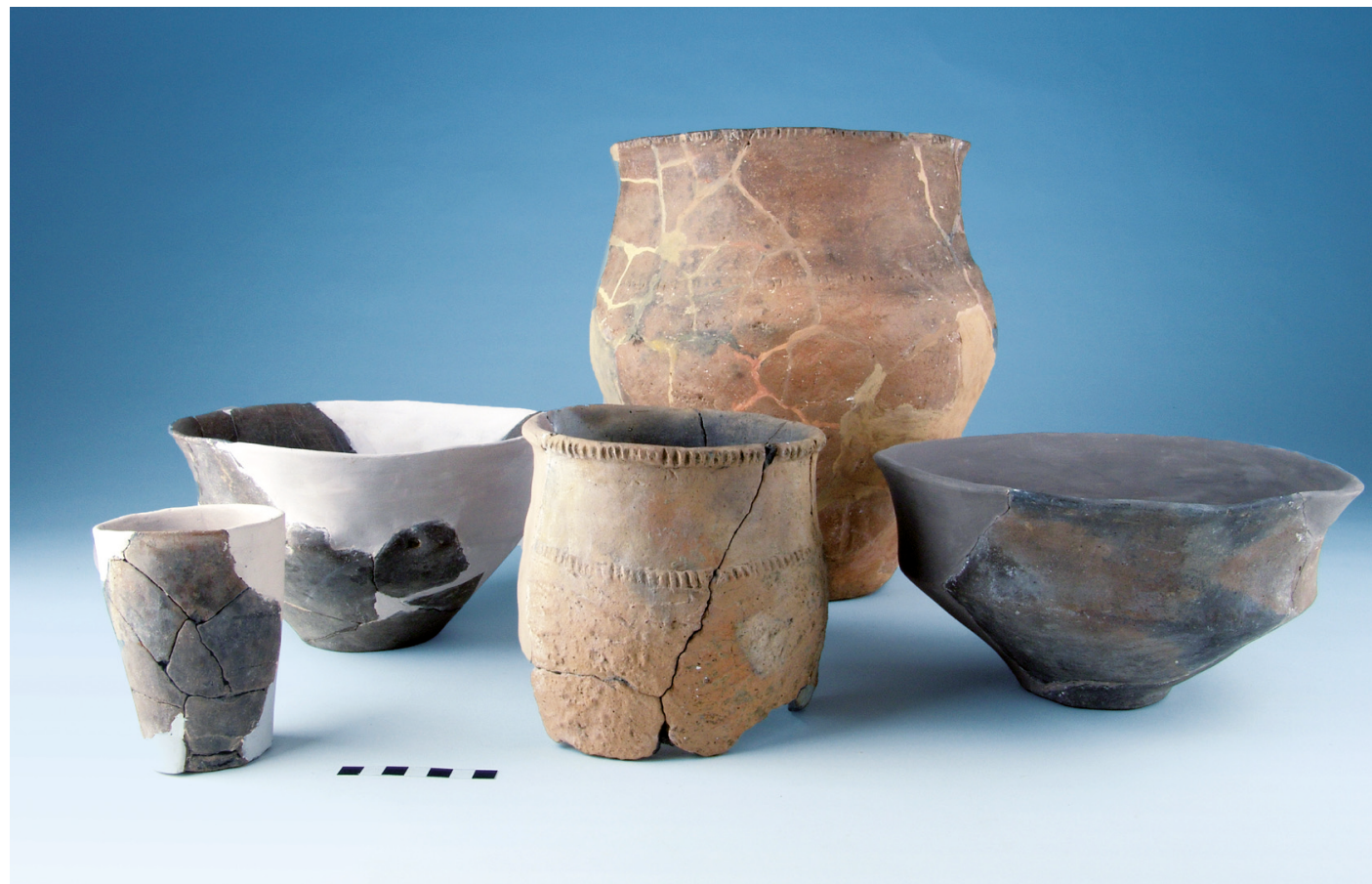

Obr. 8. Otrokovice-Kvítkovice - Chmelín 2004. Výběrová kolekce keramiky z obsahu jámy č. 5126. Foto M. Bém. Fig. 8. Otrokovice-Kvítkovice - Chmelín 2004. Selective collection of pottery from pit No. 516. Photo by M. Bém.

Chráštan (Peška 2015, Fig. 8:7) má vyšší hrdlo, nad lomem těla jedno ucho a rytou výzdobu. Podobně jako předchozí typ mísy je i tento tvar př́značný pro fáze Wachberg a Spielberg JeK (Schwamennhöfer 1991, Abb. 381 Schicht 2; Krenn-Leeb 1999, Abb. 6:C2b), ale také chamskou kulturu (Burger 1988, Taf. 20-22). Poněkud jinak profilovaná mísa se dvěma uchy se může objevit na počátku řivnáčské kultury (Pleslová-Štiková 1973, Abb. 13:1-3; 15:18).

Obecně musíme s typem nálevkovitých mís počítat od KNP prakticky po celý Baden až na počátek mladšího eneolitu, kde jejich existence patrně zaniká. Nejsou tedy př́liš dobrým chronologickým vodítkem.

Širší kónickou nádobku s rovným dnem (opět pouze ve fragmentu) a zlomek dna masivnějšího exempláře (obr. 5:5; 6:3) řadíme k typu kónických čerpáků s rovným dnem. Čerpáky jsou součástí keramického inventáře od klasické fáze badenské kultury, kde se objevují tvary s plochým dnem, kónickými stěnami a uchem převyšujícím okraj. Zástupci s rovným nebo zaobleným dnem jsou starší než hrotité, charakteristické pro postbadenské období, i když i tyto se mohou objevit ještě $v$ průběhu badenské kultury a naopak ploché dno u nich může přežívat až do mladšího eneolitu (Němejcová-Pavúková 1981, 269, obr. 5:F) např. hojně v bošácké (Pavelčik 1964, obr. 1:4), výjimečně v jevišovické kultuře (Šuteková 2008, 68-69, 108-109, Tab. P65:2; K30:6). Nejčastější analogie však nacházíme mezi klasickou badenskou keramikou na Moravě i v Dolním Rakousku (Parma - Šmíd 2007, obr. 9:9; Šmíd 2008, obr. 2:5; Furholt 2009, Taf. 49:2,5; Mayer 1996, Taf. 143:8; Schmitsberger 2005, Abb. 15:29), ale především na území dnešního Mad’arska (Banner 1956, I:9; II:1-2; 
III: 2,4; IV:1, 10, 11 ad.; Horváth 2012, Fig. 4:5). Některé formy se objeví také v chamské oblasti (Graser 1999, Abb. 3). V našem souboru působí antikvárním dojmem a může být dalším argumentem pro starobylost kolekce $\mathrm{v}$ rámci JeK s badenskými tradicemi.

\section{Kulturní a chronologická pozice nálezů}

$\mathrm{Z}$ výše uvedené analýzy dvou menších souborů keramických nádob či spíše jejich fragmentů z Otrokovic-Kvítkovic vyplývá jejich silná vazba na prostředí kultury chamské, ale také nejstarší fáze (facies) kultury jevišovické (Wachberg) na území Dolního Rakouska. Typologicky i technologicky prakticky identická keramika má k těmto entitám blíže než k nejstarším projevům JeK na Moravě, za něž jsou tradičně považovány nálezy z Grešlového Mýta. I když můžeme připustit např. možnost lokálního specifika materiálu, objevujícího se až v regionu východní Moravy, kde se $\mathrm{s}$ JeK dříve vůbec nepočítalo, zřetelné silnější vazby na vzdálenější oikumeny (Bavorsko, západní Čechy, Dolní Rakousko) přece jen překvapují. Na rozdíl od E. Ruttkay (1987) s tendencí zařadit sídlišstě v Kicking-Grubhof $\mathrm{k}$ chamské kultuře (značně vybočující již svou polohou z oblasti rozšíření na východ), která může být rovněž považována za nejstarší Jek se silnými vazbami na západ, si pro značnou vzdálenost nedovolíme náš materiál připsat přímo chamské kultuře, ale budeme jej považovat za doklady nejstarší JeK v oblasti na východ od řeky Moravy časově na úrovni fáze Wachberg nebo Grešlové Mýto. V této době jsou ostatně vztahy k chamské oblasti velice intenzívní (v Otrokovicích-Kvítkovicích překvapivě ještě více než v samotném Grešlovém Mýtě). Chronologickou pozici nálezů na počátku JeK podtrhují badenské reminiscence (čerpáky, nálevkovité mísy), byt v souboru chybí velmi typické slámování nádob. O postupném rozšiřování jevišovických prvků právě v tomto období svědčí i lokality ve východních Čechách (Cerekvice nad Loučnou, Libčany), které lze datovat shodně s naším kvítkovickým materiálem. Až budoucí výzkum ukáže, zda mají v tomto regionu jevišovické nálezy své pokračování.

Z hlediska relativní chronologie klademe tedy náš skromný soubor na počátek JeK, časově na úroveň fáze Grešlové Mýto se silnými vazbami na západ do prostředí chamské kultury, příp. do oblasti Dolního Rakouska. Mělo by jít o dobu před nástupem či průnikem kultury kulovitým amfor na naše území, nebot tyto nálezy doprovázejí na Moravě až mladší fáze jevišovického osídlení (Vysočany a Jevišovice B). Jde však o pouhou hypotézu, nebot žádný pádný důkaz k dispozici nemáme. Absolutně chronologickou pozici můžeme řešit pouze per analogiam, jelikož v kvítkovickém souboru není artefakt, který by bylo možno absolutně datovat.

$\mathrm{S}$ výjimkou problematických absolutních dat z moravských eneolitických výšinných sídlišt jako jsou Jevišovice B: 3620-3420 BC (bolerázské datum) nebo nejmladší vrstva v Brně-Líšni I: 2870-2035 BC (pro velkou chybu nepoužitelné) jsou všechna dosavadní publikovaná data JeK mladší (cf. Peška 2011, obr. 13), náleží však až mladším vývojovým obdobím jmenované kultury. Podobně datované kontexty z kultury Goldberg III, Řivnáč, Cham (John 2010, Tab. 7-9) spadají zhruba do úseku 3350/3300-3000 BC. Datum z Wachberg (KN-NR $4520 \pm 59$ BP) lze kalibrovat na 2 sigma 3372-3024 BC, datum z Kicking (jáma 1/1949) je nekorigováno a uváděno jen jako $2650 \pm 80$ bc (Ruttkay 1987, 169a d.). Nověji pořízená série dat z Meidling - Kleiner Anzingerberg kolísá mezi 3100-2870, sumarizovaně 2 sigma 2930-2880 BC (Krenn-Leeb 2003, Abb. 7, 14) a měla by být o něco mladší. $\mathrm{Z}$ druhé strany mohou být oporou data klasické fáze badenské kultury, vycházející souhrnně poněkud široce: 


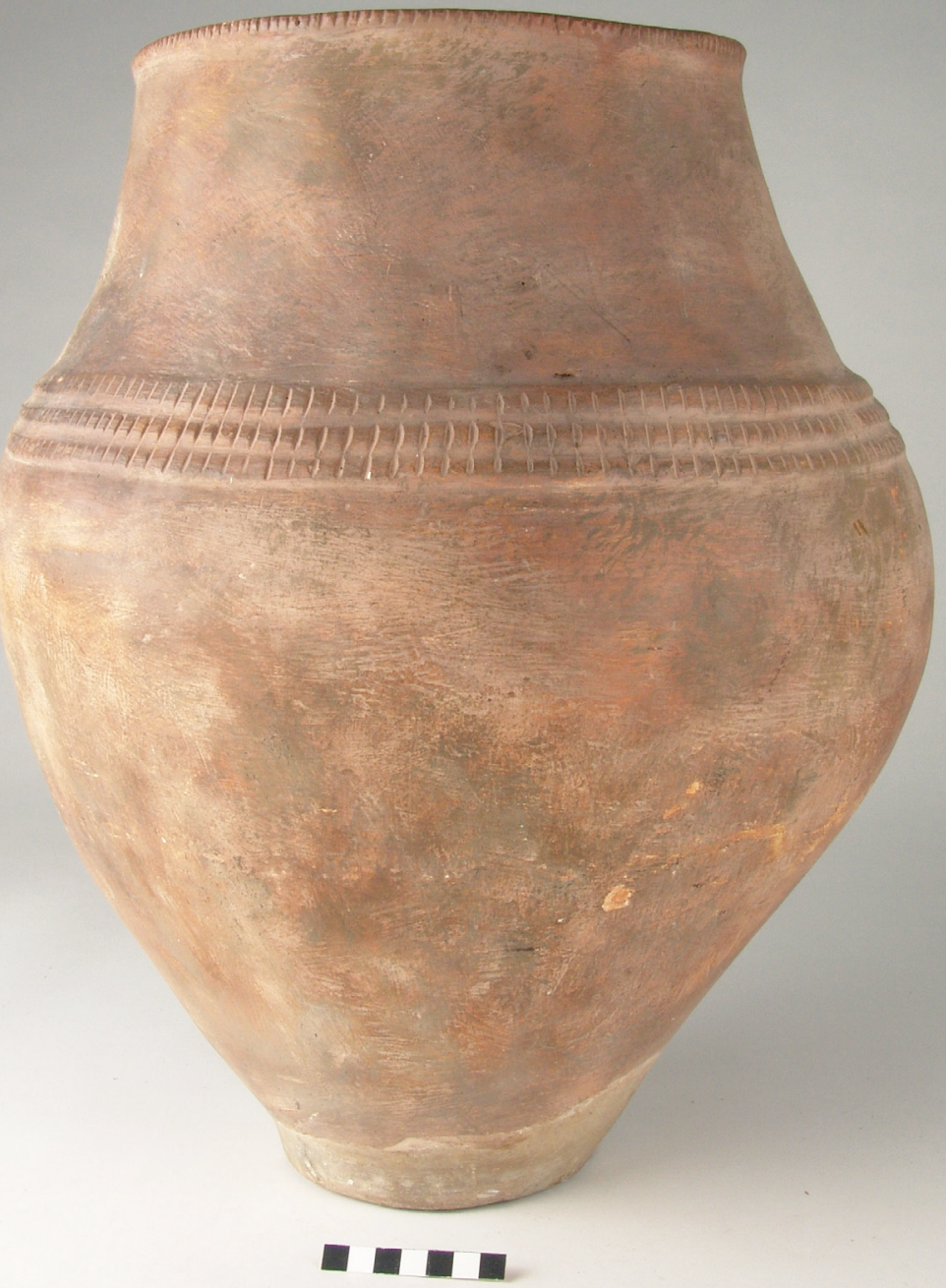

Obr. 9. Otrokovice-Kvítkovice - Chmelín 1934. Hrnec/zásobnice/amfora z jámy z roku 1934. Foto M. Kršková. Fig. 9. Otrokovice-Kvítkovice - Chmelín 1934. Pot/storage jar/amphora from a pit excavated in 1934. Photo by M. Kršková 


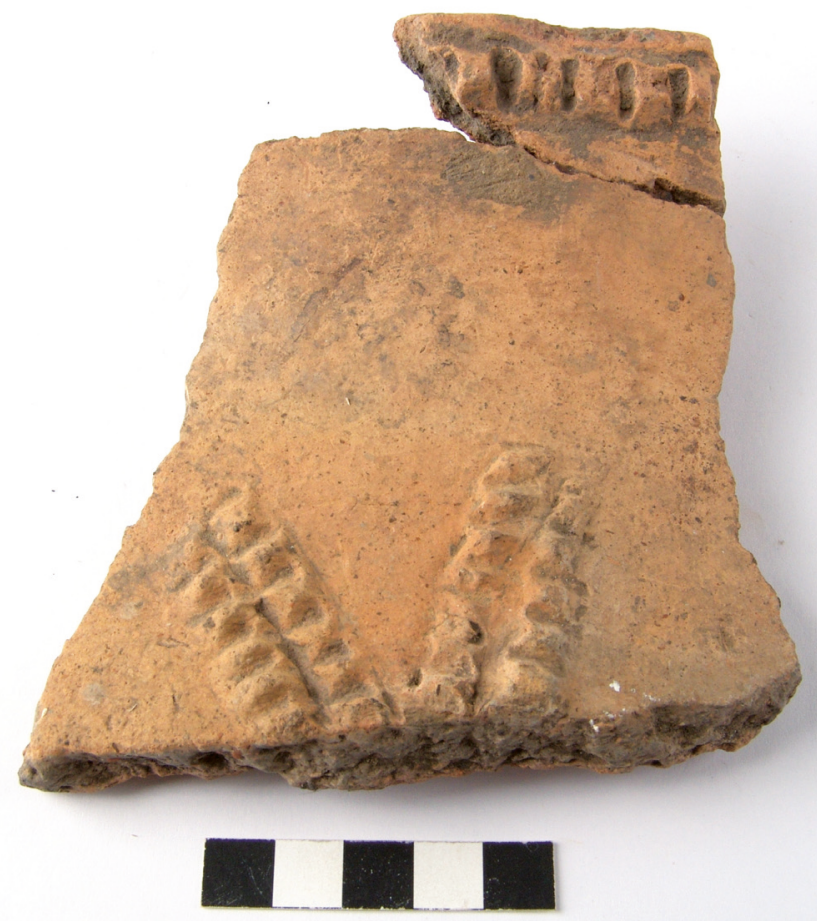

Obr. 10. Otrokovice-Kvítkovice - Chmelín 1934. Fragment nádoby s plastickou výzdobou ve formě dvojité V-lišty z jámy z roku 1934. Foto M. Kršková.

Fig. 10. Otrokovice-Kvítkovice - Chmelín 1934. Fragment of a vessel with relief decoration in the form of a double V-shaped ribbon from 1934. Photo by M. Kršková.

3750-2750 BC (2 sigma) (Ruttkay 2001, Abb. kultury, znovu otevírají otázku ne/návaznosti 13), když data ossarnské skupiny z Girm vychá- postbadenského vývoje na bolerázskou kulturu zí na 3371-3089 a 3378-3089 cal BC (Ruttkay (cf. Furholt 2007, 230-238; 2009, 232 ad.; Peš2001, 85). Nová data z Mad’arska pak vycházejí ka 2015, 106-107), která je materiálově např. i na klasický Baden jako velmi mladá rámco- v obsahu sídliště Grešlové Mýto jasně zastouvě mezi 3000-2700 BC (Horváth et al. 2008, pena (Medunová-Benešová 1973, Taf. 43-44), Fig. 4) nebo dokonce $\mathrm{s}$ ještě větším rozsahem avšak nevíme v jaké formě (nerozeznaný sídel3400-2300 BC (cf. Horváth 2012, Tabl. 4,6,7), ní horizont, impakt?). Navíc jsou v její náplni což nabádá k opatrnosti a bude muset být pře- a v náplni počínající kultury chamské nebo jezkoumáno. Nicméně dendrochronologická višovické některé společné znaky, např. plasticdata bolerázského impaktu na sídlišti v Arbon ké aplikace (hladký nebo přesekávaný pavouk, Bleiche (3384-3370 BC), jen nepatrně starší svislé paličky), objevující se na bolerázské i na než předpokládaná fáze Grešlové Mýto, a de nejstarší a starší Jek a chamské keramice (Jefacto současnost s klasickou fází badenské višovice C 1, Brno-Líšeň, I, II, Grešlové Mýto, 
Wachberg, Kicking, Vysočany), absentující však dosud na klasických badenských nádobách. U obou aplikací jsme schopni pozorovat jejich starší eneolitickou tradici (baalberská fáze KNP). Z druhé strany však lze v materiálu nejstarší JeK rozlišit řadu entit navazujících na klasickou badenskou kulturu (že by regionální záležitost?).

\section{Závěr}

Identita materiálu z obou skromných souborů z Otrokovic-Kvítkovic nás utvrzuje v tom, že nálezy patří kulturně historicky k sobě, a že máme co dočinění s reliktem nížinného sídliště počínající JeK nad levým břehem Dřevnice ve střední části východní Moravy. V tomto smyslu musíme přehodnotit dosavadní názory na původní rozšíření JeK, které svým východním okrajem asi zasáhlo i východní břeh řeky Moravy (jednorázově, opakovně?), což zřejmě bylo umožněno slabým osídlením bošáckou kulturou (cf. Peška 2013, 52-65, mapa 6). Na expanzi nositelů JeK již v zárodečném stadiu vývoje ostatně poukazují také soudobé (byt zatím spíše ojedinělé) nálezy z přrilehlé části východních Čech, kde si východně Hradce Králové a Pardubic umíme představit menší samostatnou oikumenu. Enkláva vytvořená na JZ Slovensku z lokalit v povodí Dudváhu a na pravém břehu řeky Váh bude nejspíše mladšího data a zastihuje zde již plně vyvinutou JeK.

Orientace na prostředí chamské kultury ve východním Bavorsku a v západních Čechách, příp. stejně staré facies Wachberg v Dolním Rakousku potvrzuje silné vazby na toto kulturní prostředí na počátku jevišovické kultury, kdy se na Moravě JeK z badenského (nebo boleráz- ského?) podloží teprve formuje. Časově by toto údobí mělo odpovídat fázi Grešlové Mýto JeK nebo počátku kultury Cham (Hienheim). Vztahy k bošácké entitě jasné nejsou, mělo by jít (teoreticky) o dobu před pronikáním elementů kulovitých amfor na naše území (a tím i do jevišovického prostředí). Na základě srovnání s jinými absolutně datovanými soubory v okolí by se mělo jednat o dobu ca 3300-3000 BC, což jsou data vykazovaná současně pro klasickou badenskou a začínající chamskou, příp. řivnáčskou kulturu. Časově př́liš vzdálená nejsou ani data bolerázské kultury (medián dendro 3377 BC, v Mad’arsku dokonce až po 3027 BC), $\mathrm{s}$ čímž bude nutno do budoucna ještě pracovat. V tomto směru výrazně postrádáme větší počet dat (zejména domácích) z Bolerázu i klasické badenské kultury.

Rozsahem nevelký, ale o to významnější a svým způsobem překvapivý soubor nejstarší jevišovické keramiky jednoznačně ukazuje na okupaci levého břehu řeky Moravy a značný prostorový zábor již v době formující se JeK nejen na Moravě. Úkolem do budoucna bude vyjasnit genetickou základnu JeK, za níž byla vždy považována klasická badenská kultura. Nezanedbatelná (regionálně?) se však začíná jevit také role bolerázské kultury, jejíž závěr nebude od nástupu JeK absolutně chronologicky př́liš vzdálený, když si uvědomíme, že zatím získaná a publikovaná data JeK na Moravě náleží až době plně rozvinuté kultury nebo jejímu závěru.

Za poskytnuti materiálu ke zpracováni a informace k nálezovým okolnostem, zejména staršiho souboru, jsem dikem zavázán milé kolegyni Janě Langové, článek je pak tichou vzpominkou na autora výzkumu Jiř́ho Kohoutka. 


\section{Literatura}

Banner, J. 1956: Die Péceler Kultur. Budapest.

Burger, I. 1998: Die Siedlung der Chamer Gruppe von

Dobl, Gemeinde Prutting, Landkreis Rosenheim und ihre Stellung im Endneolithikum Mitteleuropas, Materialhefte zur bayerischen Vorgeschichte 56, Reihe A, Fürth/Bay.

Ciugudean, H. 2000: Eneoliticul final în Transilvania şi Banat: kultura Coțofeni, Timişoara.

Čižmářr, M. 2004: Encyklopedie hradišt na Moravě a ve Slezsku. Praha.

Čižmář Z. 2002: Mašovice (okr. Znojmo), Přehled výzkumů 43 (2001), Brno, 182-183.

Čižmár̆, Z. 2003: Mašovice (okr. Znojmo), Přehled výzkumů 44, Brno, 218.

Dobeš, M. - Šumberová, R. 2015: Další doklady osídlení z druhé půle středního eneolitu v trase kolínského silničního obchvatu, Archeologie ve středních Čechách 15, 515-541.

Době̌, M. - Šumberová, R. - Kyselý, R. 2013: Bošácká keramika z Kolína. Doklad kontaktu postbadenských kultur v závěru středního eneolitu, Archeologické rozhledy LXV, 382-400.

Furholt, M. 2007: Radiokarbonové datování. In: Šebela, L. a kol., Hlinsko. Výšinná osada lidu badenské kultury, Spisy Archeologického ústavu AV ČR Brno 32, Brno, 225-239.

Futholt, M. 2009: Die nördlichen Badener Keramikstile im Kontext des mitteleuropäischen Spätneolithikum (3650-2900 v. Chr.), Studien zur Archäologie in Ostmitteleuropa 3. Bonn.

Graser, S. 1999: Das Erdwerk von Hadersbach, Stadt Geiselhöring, Lkr. Straubing-Bogen. In: Schlichterle, H. - Strobel, M. (Hrsg.) Aktuelles zu Horgen - Cham - Goldberg III - Schnurkeramik in Süddeutschland. Rundgespräch Hemmenhofen 26. Juni 1998, Hemmenhofer Skripte 1, Geienhofen-Hemmenhofen, 49-54.

Horváth, T. - Svingor, S.É. - Molnár, M. 2008: New Radiocarbon Dates for the Baden Culture, Radiocarbon 50, 447-458.

Horváth, T. 2012: Networks and Netwars: New perspectives on the Late Copper Age and Early Bronze Age. Typo-chronological relationships of te Boleraz/Baden/Kostolac finds at the site of
Balatonőszöd-Temetői dűlő, Hungary, BAR International Series 2427, Oxford.

Hrala, J. 1959: Několik nálezů z Kolínska, Archeologické rozhledy XI, 21-25.

Jilková, E. 1957: Západní Čechy na počátku doby bronzové, Památky archeologické XLVIII, 15-57.

John, J. 2010: Výšinné lokality středního eneolitu v západních Čechách. Opomíjená archeologie 1. Plzeň.

Kalferst, J. 2001: Neolitické a eneolitické sídliště v pískovně „Na požárce“ k.ú. Obědovice, okr. Hradec Králové. In: Otázky neolitu a eneolitu našich zemí. Sborník referátů z 18. pracovího zasedání badatelů pro výzkum neolitu a eneolitu Čech, Moravy a Slovenska, Mostkovice 14. - 17. září 1999. Pravěk, Supplementum 8. Brno, 53-63.

Kalferst, J. - Prostřednik, J. 1998: Nové nálezy bošácké skupiny ve východních Čechách, Archeologické rozhledy L, 586-599.

Kalferst, J. - Prostřednik, J. 2000: Sídlištní objekt bošácké skupiny z Obědovic (okr. Hradec Králové), Archeologické rozhledy LII, 507-515.

Kalicz, N. 1968: Die Frühbronzezeit in Nordost-Ungarn. Budapest.

Kohoutek, J. 1996: Počátky a rozvoj regionálního bádání na Zlínsku, Archeologické rozhledy XLVIII, $559-563$.

Kohoutek, J. 2006: Otrokovice (k.ú. Kvítkovice u Otrokovic), okr. Zlín, Přehled výzkumů 47, Brno, 110-111, 132-133, 147, 159, 271.

Kohoutek, J.- Langová, J. 2001: Otrokovice, PV 2000 (42), Brno, 137,167.

Kohoutek, J. - Parma, D. 2006: Otrokovice, okr. Zlín, Přehled výzkumů 47, Brno, 147-148, 159.

Koštuřik, P. 2007: Eneolitické osídlení Hradiska u Kramolína ve středoevropských souvislostech. Ústav archeologie a muzeologie Filozofická fakulta Masarykovy univerzity Brno. Brno.

Krenn-Leeb, A. 1999: Die fazies Spielberg als Mittler zwischen der älteren und jüngeren Jevišovice-Kultur in Niederösterreich? Neue Erkenntnisse zum älteren Abschnitt des Endneolithikums, Mitteilungen der Anthropologischen Gesellschaft in Wien 129, 45-67.

Krenn-Leeb, A. 2003: Erste Radiokarbondaten vom Kleinen Anzingerberg in Meidling im Thale, VB 
Krems, Niederösterreich. In: Jerem, E. - Raczky, P. (Hrsg.), Morgenrot der Kulturen. Frühe Etappen der Menschheitsgeschichte in Mittel- und Südosteuropa. Festschrift für Nándor Kalicz zum 75. Geburtstag. Archaeolingua 15, Budapest, 431-444.

Mayer, Ch. 1996: Die Stellung der Funde vom Grasberg bei Ossarn im Rahmen der Badener Kultur, Mitteilungen der Prähistorischen Kommission der Österreichischen Akademie der Wissenschaften Band 30, Wien.

Medunová-Benešová, A. 1964: Eneolitické výšinné sídliště Staré Zámky v Brně-Líšni. Památky archeologické LV, 91-155.

Medunová-Benešová, A. 1967: Eneolitické mohyly ohrozimského typu na Moravě, Památky archeologické LVIII, 341-380.

Medunová-Beně̌ová, A. 1972: Jevišovice - Starý Zámek. Schicht B - Katalog der Funde, Fontes Archaeologicae Moravicae T. VI. Brno.

Medunová-Benešová, A. 1973: Grešlové Mýto, Äneolithische Höhensiedlung „Nad Mírovcem“, Katalog der Funde. Fontes Archaeologicae Moravicae T. VII. Brno.

Medunová-Benešová, A. 1981: Jevišovice - Starý Zámek. Schicht C2, C1, C - Katalog der Funde, Fontes Archaeologiae Moravicae XIII. Brno.

Nevizánsky, G. 2001: Delené misy badenskej kultúry. In. Otázky neolitu a eneolitu našich zemí. Sborník referátů z 18. pracovního zasedání badatelů pro výzkum neolitu a eneolitu Čech, Moravy a Slovenska, Mostkovice 14.-17. záŕí 1999, Pravěk Supplementum 8, Brno, 311-324.

Němejcová-Pavúková, V. 1981: Náčrt periodizácie badenskej kultúry a jej chronologických vztahov k juhovýchodnej Európe, Slovenská Archeológia XXIX, 261-296.

Parma, D. - Šmíd, M. 2007: Ossarnský hrnec ze Sudoměřic, okr. Hodonín, In: Otázky neolitu a eneolitu našich zemí. Sborník referátů z 25. zasedání badatelů pro výzkum neolitu Čech, Moravy a Slovenska, Hradec Králové 30. 10.-2. 11. 2006, Archeologické studie Univerzity Hradec Králové svazek 1, 131-146.

Pavelčik, J. 1964: Eneolitická skupina s keramikou bošáckého typu na Moravě, Památky archeologické LV, 279-293.
Pavelčik, J. 1993: Bošácká kulturní skupina. In: Podborský, V. a kol.: Pravěké dějiny Moravy, Brno, 200-204.

Pavelčk, J. 2004: Stratigrafická situace výšinné osady Bánov-Hrad In: Hänsel, B. - Studeníková, E. (Hrsg.) Zwischen Karpaten und Agäis. Neolithikum und ältere Bronzezeit. Gedenkschrift für Viera Němejcová-Pavúková. Internationale Archäologie, Studia honoraria 21. Rahden/Westf., 251-270.

Peška, J. 2000: K vybraným problémům relativní chronologie v období mladého a pozdního eneolitu na Moravě, Pravěk NŘ 9, Brno, 243-268.

Peška, J. 2001: Das Besiedlungsbild des Spätneolithikums un der Frühbronzezeit in Südmähren. In: Lippert, A. - Schultz, M. - Shennan, S. - TeschlerNicola, M. red.: Mensch und Umwelt während des Neolithikums und Frühbronzezeit in Mitteleuropa, Intenationalee Workshop vom 9.-12. November 1995, Wien, Internationale Archäologie 2, Rahden/Westf., 139-148.

Peška, J. 2011: Nové poznatky o jevišovickém osídlení v regionu střední Moravy. In: Popelka, M. - Šmidtová, R. (eds.), Otázky neolitu a eneolitu našich zemí. Sborník referátů z 28. zasedání badatelů pro výzkum neolitu a eneolitu (nejen) Čech, Moravy a Slovenska, Mělník 28. 9.-1. 10. 2009, Praehistorica XXIX, Praha, 297-322.

Peška, J. 2013: Morava na konci eneolitu. Olomouc.

Peška, J. 2015: A small contribution to the knowledge of Baden culture in Moravia and the present state of research. In: Zastawny, A. - Nowak, M. (eds.), The Baden Culture around the Western Carpathians, Via Archaeologica. Źródła z badań wykopaliskowych na trasie autostrády A4 w Małopolsce, Kraków, 95-118.

Peška, J. - Tajer, A. 2009: Příspěvek k poznání jevišovického osídlení na střední Moravě. In: M. Bém J. Peška (eds.): Ročenka 2008, Olomouc, 59-107.

Pleslová-Štiková, E. 1973: Die Kultur mit kannelierter Keramik in Böhmen. In: Symposium über die Entstehung und Chronologie der Badener Kultur, Bratislava, 393-425.

Prostřednik, J. 2001: Chamská kultura v západních Čechách, Praehistorica XXV-XXVI, 9-177.

Ruttkay, E. 1987: Die Chamer Gruppe in Niederöstrreich? Siedlungsfunde von Kicking, Annales des Naturhistorisches Museum in Wien, 88, 163-181. 
Ruttkay, E. 2001: Wachberg bei Melk - eine Siedlung der frühen Jevišovice-Kultur. Überlegungen zur Chronologie des älteren Endneolithikums in Ostösterreich. In: Gohlitz, T.H. - Reisch, L. (Hrsg.) Die Stellung der endneolithischen Chamer Kultur in ihren räumlichen und zeitlichen Kontext. Kolloquien des Institutes für Ur- und Frühgeschichte Erlangen 1, 56-85.

Schmitsberger, O. 2005: Eine Siedlung der klassischen Badener Kultur in Stoitzendorf im Weinviertel, Fundberichte aus Österreich 43, 2004, Wien, 135-196.

Schwamennhöfer, H. 1991: Endneolithische Besiedlung am Wachberg bei Melk, Fundberichte aus Österreich 29, 1990, Wien, 97-152.

Sachsse, C. 2010: Untersuchungen zu den Bestattungssitten der Badener Kultur, Universitätsforschungen zur Prähistorischen Archäologie 179, Bonn.

Šebela, L. 1989: Nález sekeromlatu typu Halfing-Linz na Moravě, Archeologické rozhledy XLI, 193-196.

Šmíd, M. 2003: Výzkum mohylového pohřebiště v poloze „Džbán“ u Náměště na Hané, okr. Olomouc, Pravěk NŘ 13, 91-112.

Šmíd, M. 2008: Příspěvek k poznání vývoje kultury s kanelovanou keramikou na střední Moravě, Pravěk Nॅ̆ 17, 2007, Brno, 89-119.

Šmíd, M. - Přichystal, A. 2015: Eneolitická hradiska na Prostějovsku Ohrozim - Čubernice a Prostějov-
Čechovice - Čechovsko, Pravěk Supplementum 29, Brno.

Štrof, A. 1994: Eneolitické osídlení Hradiska u Svitávky, okr. Blansko, Pravěk N $\check{R}$ 2, 1992, Brno, 159-181.

Šuteková, J. 2008: Bošácka skupina a jevišovická kultúra na Slovensku. Disertačná práca. Filozofická fakulta, Univerzita Komenského v Bratislave. Bratislava.

Vokolek, V. 1982: Neolitické sídliště v Cerekvici nad Loučnou, Zpravodaj Krajského muzea východních Čech IX/1, Hradec Králové, 61-80.

Vokolek, V. - Zápotocký, M. 1990: Východní Čechy ve středním eneolitu (otázka zásahu bošácké skupiny), Památky archeologické 81, 24-58.

Výročni zpráva ÚAPP Brno 2000, Brno 2001.

Zastawny, A. 2011: Chronologia i formy oddziaływań kompleksu badeńskiego w Małopolsce, In: Popelka, M. - Šmidtová, R. (eds.), Otázky neolitu a eneolitu našich zemí. Sborník referátů z 28. zasedání badatelů pro výzkum neolitu a eneolitu (nejen) Čech, Moravy a Slovenska, Mělník 28. 9.-1. 10. 2009, Praehistorica XXIX, Praha, 431-450.

Zápotocký, M. - Zápotocká, M. 2008: Kutná hora - Denemark. Hradiště řivnáčské kultury (ca 3000-2800 přn.n.l.). Památky archeologické - Supplementum 18. Praha. 


\section{Jevišovice Culture in East Moravia?}

Besides the traditional distribution area of Jevišovice Culture as a part of the post-Baden Late Eneolithic cultural complex in SW Moravia and in the adjacent Lower Austria, we find this culture since the beginning also in East Bohemia (Cerekvice nad Loučnou, Libčany, Proseč), and a later enclave also arose in SW Slovakia (Šuteková 2008, obr. 18-19). A new surprising finding is represented by the remnant of a lowland settlement of Jevišovice Culture at Otrokovice-Kvítkovice, Chmelín site. The finding comprises the content of a pit (No. 516, excavation in 2004) and identification of one ceramic vessel and two typical shards from the same locality in collections of the Zlín Museum (amateur excavation in 1934).

Ceramic finds with the same typological and technological characteristics, represented by pots, sharply profiled funnel bowls, a deep tureen-shaped bowl (Fig. 5-7) etc., have closest parallels in the Cham Culture in West Bohemia and East Bavaria, or in the earliest phase of Jevišovice Culture on the territory of Lower Austria (Wachberg phase) where we find more distinct analogies than in the Grešlové Mýto phase in Moravia. Due to considerable geographical distance, however, we do not consider cultural affiliation to the Cham area, but we regard this material as the earliest display of Jevišovice Culture at the same chronological level as Grešlové Mýto. This chronological position is underlined by the presence of at least two dipper cups with conical body and flat bot- tom, which are typical of the classical Baden Culture. Per analogiam, we place this period according to absolute dating to $3300-3000 \mathrm{BC}$, which also is the period of classical Baden Culture and the beginning of Cham Culture or Řivnáč Culture respectively. Not only absolute dates, but also many identical attributes on pottery, e.g. relief appliqués in the form of spiders and hanging sticks which are present on the Boleráz and the oldest Jevišovice and Cham pottery but absent on vessels of classical Baden Culture, as well as the presence of pottery in the collection from Grešlové Mýto, raise again the question of whether or not the post-Baden development followed immediately after the Boleráz Culture (cf. Furholt 2007, 230-238; 2009, 232 sq.; Peška 2015, 106-107).

The site above the right bank of the rivulet Dřevnice in Otrokovice-Kvítkovice refers to colonisation of the eastern bank of the river Morava by people of Jevišovice Culture in its initial phase, which was most probably enabled by only scattered settlement of Bošáca Culture in the region. Similar dating is also possible with finds from East Bohemia (Cerekvice nad Loučnou, Libčany). A part of Southwest Slovakia was not occupied until the fully developed Jevišovice Culture. In the future we thus must answer the question of genesis of Jevišovice Culture: has it developed only from classical Baden Culture, or as well from Boleráz Culture (or with regional differences?). 
doc. PhDr. Jaroslav Peška, Ph.D.

- Archeologické centrum Olomouc

U Hradiska 42/6, 77900 Olomouc, Česká republika

peska@ac-olomouc.cz 